\title{
Management and Assistance Village Fund Allocation towards Welfare
}

\author{
Femei Purnamasari ${ }^{1}$, Dharmayani ${ }^{2}$ \\ \{femeipurnamasari@radenintan.ac.id ${ }^{1}$, dharmayani@ radenintan.ac.id ${ }^{2}$ \}
}

UIN Raden Intan Lampung, Indonesia ${ }^{1}$, UIN Raden Intan Lampung, Indonesia ${ }^{2}$

\begin{abstract}
Village Fund Allocation (ADD) is one of the most important aspects of a village to carry out government programs, including programs for the welfare of community. The purpose of this study is to determine the ADD management towards the welfare improvement of the local community and as a reference and guideline in making decisions taken for the ADD program[1]. This is a field research which uses Miles model analysis and Huberman with deductive thinking method. In the end, the management of ADD has been going well. The promoting factor for improving the welfare of the community in this study is community participation in planning, policy support from the government, the quality of human resources. While the inhibiting factors are low synchronization between planning at the Village and District levels, the limited amount of Village Fund Allocation (ADD) and the lack intensity of socialization to the community, and the low level of education of village officers which can slow down the Village Fund Allocation management (ADD)[2]. The role of legal assistance for ADD recipients is more as facilitator and legal advisor for ADD recipients and village officers, also minimizes the cheating level for ADD recipients and implementers.
\end{abstract}

Keywords: Village Fund Allocation, Management, Assistance, Welfare

\section{Introduction}

Village Fund Allocation (ADD) is one of the most important aspects of a village to carry out government programs, including programs for the welfare of the people in the area.

Based on law No. 6 of 2014 concerning villages, ADD must acknowledge this as a pilot project, especially regarding the delegation of authority to the village government for the implementation of the village fund budget where the management of these funds is quite large[3]. So that managed village funds can become like 'bait' which makes village officers entangled in a spiral of social conflicts and interests that eventually enter the realm of law.

This is a dilemma for village officers in managing village funds, with various forms of non-crime that lead to criminal acts of corruption, for example, embezzlement, budget abuse, abuse of authority, illegal fees, budget markups, fictitious reports, budget cuts and bribery[4]. Then we can also find various other modes of utilizing village funds in private coffers. Collecting or cutting village funds by sub-district and district officials with various activity gaps so that village officials become targets for this error. There are many expressions of disappointment with village assistants, including legal assistance that has not been maximally utilized its roles and functions at the village, sub-district and even district-city levels[5]

In addition to the lack of curiosity and ignorance of village assistants and village legal assistants, this paper can seek to see that there are various conflicts of interest to utilize village funds for hidden group and personal interests with various hidden agendas or no transparency 
of managed village funds, so that the role of legal assistants is a dilemma. On one hand its role is so important in assisting villages and sub-districts, but on the other hand it becomes a frightening specter due to reduced budgets. This side then arises various conflicts of interest that lead to disharmony between the government and village assistants, and legal assistants in several villages and districts.

Based on this phenomenon, the main focus in this research is what the impact of the implementation of the 2020 village fund allocation program on improving the welfare of the community in South Lampung Regency is and how the implementation and impact of the ADD 2020 program on improving community welfare in an Islamic economic perspective is.

\section{Theoretical Framework}

\subsection{Village Fund Allocation Program (ADD)}

The ADD program objectives, as stated in the ADD program technical instructions, are[6]:

1. Improve the implementation of village government in implementing government, development and community services according to their authority.

2. Increase the capacity of community institutions in the village in planning, implementing and controlling development in a participatory manner in accordance with the potential of the village.

3. Increasing income distribution, job opportunities and business opportunities for rural communities.

4. Encouraging increased self-help and community cooperation.

The ADD program is a package of activities that aims to help the village government, which has the following management principles, namely:

1. ADD financial management is an integral part of village finances in the village budget.

2. All activities funded by ADD are planned, implemented and evaluated openly by involving all elements of the village community.

3. All activities must be accounted for administratively, technically and legally.

4. ADD is implemented using the principles of being thrifty, directed and controlled.

\subsection{Village Fund Allocation (ADD)}

Village fund allocation is intended to finance village government programs in carrying out government activities, development, and empowerment of village communities. The objectives of village fund allocation are:

1. Reducing poverty and reducing inequality.

2. Improve development planning and budgeting at the village level and community empowerment.

3. Increasing rural infrastructure development.

4. Increasing the security of socio-cultural religious values in the context of realizing an increase in social welfare.

5. Improve services to rural communities in order to increase social and economic activities of the community.

6. Encouraging increased empowerment and community cooperation.

7. Increase village and village community income through BUMK Village Owned Enterprises. (Chabibsoleh, HeruRocmansjah, Op.Cit. P. 62). 
$30 \%$ (thirty percent) of the allocation of village funds received by the village is used for operational costs for running the village government and the BPD, while $70 \%$ (seventy percent) is used for empowering village communities. Of the $30 \%$ (thirty percent) of the village fund allocation is used for operational implementation of the village government and BPD such as: village operational costs, BPD operational costs, operational costs of the village fund allocation organizing team. Of the $70 \%$ (seventy percent) used for the community, such as: development of village economic facilities and infrastructure, empowerment in the fields of education, health and gender main management, community economic empowerment, especially to alleviate poverty and financial support for the head of village community institutions. BUMK, business groups according to the economic potential of the village community, as well as financial assistance to institutions in the village such as LPMD, RT, RW, PKK, Karang Taruna, Limnas and so on[2].

\subsection{The Concept of Community Welfare}

Community welfare is a condition showing the state of community life which can be seen from the standard of community life. (Badrudin, Rudy, Regional Autonomy, Yogyakarta: UUP STIM YKPN 2021, p. 146). According to Sudarsono, people's welfare is in a good economic condition due to the enactment of regulations in the economy that regulate the activities of all parties and the distribution of community income as a result of these economic activities (Sudarsono, PengantarEkonomiMikro, (Jakarta: LP3ES, 1982).

Community welfare can be measured from indicators. Welfare indicators are a measure of reaching a society where the community can be said to be prosperous or not according to several experts (Bappenas, Central Bureau of Statistics, Income Level, Expenditure Composition, Education, Health, Housing).

\subsection{ADD Legal Assistance}

In providing legal assistance for the implementation of village funds, the role is very important and there is an understanding of legal assistance by the village head and village officials, so that legal assistants can optimize their role in providing further intervention and prevention of things that will lead to criminal acts of corruption and misconduct. [7] the use of ADD so that it is not limited to the authority given, Where the implementation of village funds must refer to regulations and laws.

\section{Methodology}

\subsection{Population and Sample}

The researcher uses qualitative data in the form of concepts or abstract meanings (primary data and secondary data). The primary data were obtained from the results of interviews using questions to the community or village officials regarding the implementation of community welfare improvement programs. Secondary data is a source of research data obtained indirectly through intermediary media (obtained or recorded by other parties) and is complementary in nature. Secondary data is in the form of library sources that can support research writing and is obtained from relevant literature on the problem, as a basis for understanding the object of research and for analyzing appropriately. 
The population in this study was village officers, community leaders, and related communities. Sampling was 137 respondents based on the consideration that this number was sufficient with a sampling error rate of $15 \%$ and a confidence level of $85 \%$ (Bungin, 2001, p.129). Sampling was obtained using the formula proposed by Husein Umar (2003, p.59). He argues that to calculate the size of the sample can be done using the Slovin technique, namely the formula (Johan Santoso and NugrohoAlamjayaSutjipo 2013, p. 6):

$$
\begin{aligned}
& n=\frac{\mathrm{N}}{1+\mathrm{N}(\mathrm{e})^{2}} \\
& \text { Note : } \\
& \mathrm{n}=\text { Member/unit of sample } \\
& \mathrm{N}=\text { Number of population } \\
& \mathrm{e}=\text { toleranced error }(0.15 \text { or } 15 \%)
\end{aligned}
$$

\subsection{Data Collecting Technique}

Methods used in this research are observation, interview, documentation. In this research, observation used the non-participatory type of observation where the observer is not involved in the activity being observed. The form of interview used is free and guided interviews. Free interview is an interview process in which the interview does not directly lead to questions and answers on issues of the research focus (Nasution, p. 64). Determining the source of data for the interviewee was done purposively, that is, selected with certain considerations and goals for people who are considered to know the social situation especially those related to the welfare of the community around the Rejosari Mataram village. While in documentation, the researcher collects data in the form of notes, archives, and so on relating to matters relating to this research in the form of data on public officials and related parties.

\subsection{Data Processing Technique}

After conducting the research, the data collected through interview will be analyzed with the following steps; they are editing, classification, interpretation, data analysis techniques. The method of data management and analysis used by researchers is qualitative analysis. In qualitative research, new research steps are clearly known after the research is completed. Data analysis is the process of systematically searching and compiling data obtained from interviews, field notes, and other materials, so that they can be easily understood, and the findings can be shared with others (Sugiyono, Op.Cit, p. 2). Data analysis in this field used the Miles and Huberman model. Miles and Huberman argued that activities in qualitative data analysis were carried out interactively and continued to completion, so that the data was saturated. Activities in data analysis are namely data reduction, display data, conclusion drawing / verification. The data analysis steps are shown in Figure 1: 


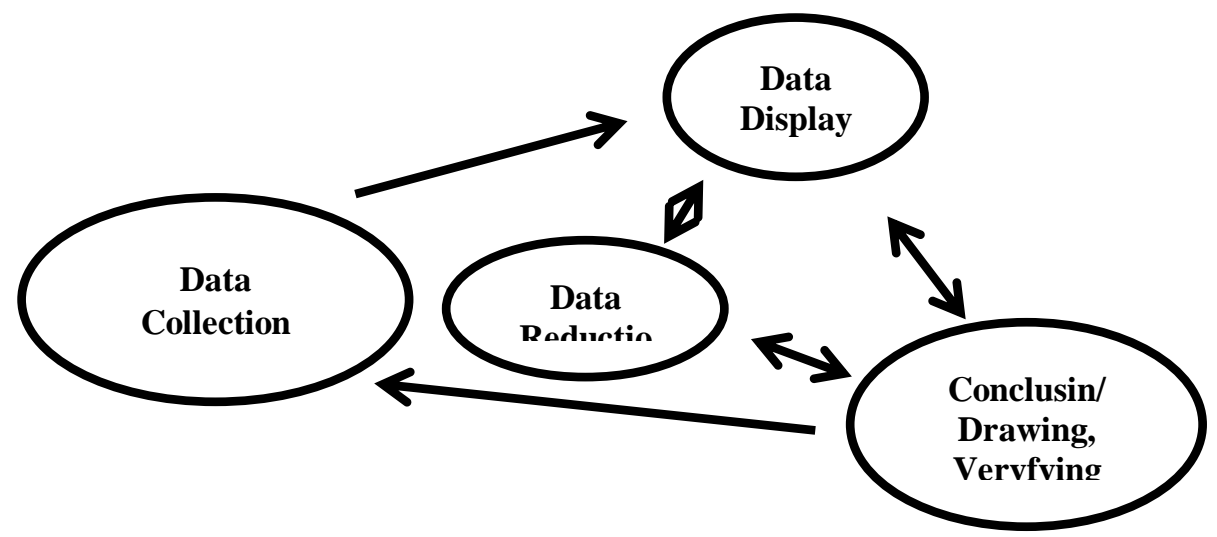

Fig. 1. Component in Data Analysis

\section{Result and Discussion}

\subsection{How is the Management of Village Fund Allocation towards Community Welfare in South Lampung?}

There are several steps in ADD management in order to achieve community welfare. They are planning, implementation, business arrangement, reports and accountability. Village Fund Allocation (ADD) management planning in physical development can be seen from the planning procedure that involves the community and community leaders involved in planning, by giving the community the authority to provide ideas / thoughts to determine development, such as development, roads, construction of puskesmas facilities, repairing fences, constructing drilling wells, repairing facilities and infrastructure, which prioritize the interests of the community first for the management of Village Fund Allocation (ADD) can be done properly. The management of the Village Fund Allocation (ADD) in the physical development of Fajar Baru Village has gone well. The existing planning process has been carried out properly, in this case the village government involves all elements of society in Fajar Baru Village who are influential in the village such as community leaders, traditional institutions, religious leaders, RT and the community in terms of contributing ideas, thoughts and energy. so that the planning process can run according to the aspirations of the community.

Implementation of Village Fund Allocation (ADD) management in the physical development of Fajar Baru Village carried out from 2017 to now has gone well and is in accordance with the planning discussed even though the funds owned by the village government are very limited. The problems that exist are lack of supervision by the Activity Implementation Team (TPK). While for business arrangement, Village Fund Allocation (ADD) management efforts in village physical development has been based on government procedures and regulations. the Village Fund Allocation (ADD) management report in the physical development of the Village has been reported to the community and BPD.

Apart from being constrained by insufficient ADD funds, the funds obtained are only focused on village operations, village apparatus spending and the Village Consultative Body 
(BPD), this is for village apparatus spending by $60 \%$ and for economic activities it can only be seen from the percentage of use of village fund allocations. $35 \%-45 \%$, like Rejomulyo Village $40 \%$. Among the 20 hamlets in Jati Agung Subdistrict, the best among other villages is Fajar Baru hamlet both administratively and in field management, both in the distribution of village fund allocations for each post, such as physical development, assistance from community institutions, economic empowerment community and village operations are in accordance with government regulations as it should be.

\subsection{Community Welfare}

Community welfare can be measured through several indicators, welfare indicators are a measure of the achievement of a community where people can be said to be prosperous or not as indicators, namely: education level, health level, community income level, community expenditure composition, and community housing level which is the benchmark. community welfare in the ADD program. So based on this, it can be seen from table 2 below:

Tabel 2 Welfare Indicator before and after ADD

\begin{tabular}{|c|c|c|c|}
\hline Indicator & Before ADD & After ADD & Information \\
\hline $\begin{array}{l}\text { Education } \\
\text { Level }\end{array}$ & $50 \%$ & $60 \%$ & Increased \\
\hline Health Level & $\begin{array}{l}\text { Medical } \\
\text { Delivery 85\% }\end{array}$ & $95 \%$ & Increased \\
\hline $\begin{array}{l}\text { Community } \\
\text { Income Level }\end{array}$ & $\begin{array}{l}\text { Rp.1.000.000- } \\
1.500 .000\end{array}$ & $\begin{array}{l}\text { Rp.1.000.000- } \\
1.800 .000\end{array}$ & Increased \\
\hline $\begin{array}{l}\text { Community } \\
\text { Expenditure }\end{array}$ & Rp. 800.000 & Rp. 800.000 & Has not increased \\
\hline Housing Level & $60 \%$ & $75 \%$ & $15 \%$ increase \\
\hline $\begin{array}{l}\text { Sewer } \\
\text { Infrastructure }\end{array}$ & $45 \%$ & $90 \%$ & increased $45 \%$ \\
\hline
\end{tabular}

Source: processed primary data

The impact of the ADD program in the Mataram rejosari in the field of education has not been felt by the surrounding community, because the allocation of these funds has not been allocated to education. With the construction of culverts and clean water sanitation, health sanitation will be healthier and will bring prosperity to the community at the health level. While the existence of this ADD does not have a positive impact on people's income, this is because the ADD program and management in Jati Agung Subdistrict, Fajar Baru Village lacks community economic empowerment programs. Community economic empowerment programs in the form of farmer groups, handicrafts by PKK mothers exist, but the management has not been well managed so that economically it has not been able to empower the community as a whole.

When viewed from the housing indicator, residents are not said to be prosperous because the building area does not meet the welfare category. Some of the indicators that have been described have shown that ADD has a positive impact on the surrounding community, such as not having to use river water anymore to fulfill clean water needs, even though it has not been able to meet $100 \%$ of clean water needs. From the explanation above, it can be seen that the 
objectives of the village fund allocation program in Rejosari Mataram Subdistrict can be said to be achieved, namely increasing infrastructure development, and increasing the practice of socio-cultural values. Meanwhile, the increase in village and community income has not been achieved as a whole, due to constraints on insufficient funds and the mismatch of programs arranged by the local village government. The village administration has not prioritized productive economic activities as one of the programs from the allocation of village funds, village officials have prioritized the construction of culverts, roads, and clean water sanitation which is very lacking so that it becomes the need of the local community.

\subsection{How is Legal Assistance towards Efforts to Improve the Welfare of Village Communities in South Lampung Regency?}

First, there is legal assistance for ADD recipients so that ADD recipients avoid things that will lead to ADD abuse.

The two legal assistants here play more roles as facilitators and legal advisors for ADD recipients and their devices, the three legal assistants here also play a role in minimizing the level of cheating for ADD recipients and implementers themselves

\section{Conclusion}

In accordance with the mandate of the Law on Village Fund Allocation Management for the welfare of the people of South Lampung, the planning for the management of Village Fund Allocation (ADD) in the physical development of FajarBaru Village has gone well. The existing planning process has been carried out properl. In this case the village government involves all elements of society in the village who are influential in the village such as community leaders, traditional institutions, religious leaders, RT and the community.

The Supporting Factors in the implementation of Village Fund Allocation management in this study include community participation in planning, policy support from the government around the RejosariMataram village, the quality of human resources, implementation and responsibility for providing ideas / thoughts and energy, as well as policy support from the government. South Lampung Regency by issuing a regulation in the form of a guidebook for implementing the management of Village Fund Allocation (ADD). While the inhibiting factors in managing the Village Fund Allocation (ADD) in the physical development of JatiAgung Subdistrict, namely the low synchronization between planning at the village and sub-district levels, the limited amount of Village Fund Allocation (ADD) and lack of intensity of socialization to the community, and the low level of educational equipment which can slow down the management of Village Fund Allocation (ADD).

Whereas in the implementation of legal assistance for ADD recipients, so that ADD recipients avoid things that will lead to abuse and here the assistance plays a more role as a facilitator and legal advisor for ADD recipients and their devices, and minimizes the level of cheating for ADD recipients and implementers themselves. Whereas community involvement in this case is in accordance with the Law, following the growth of the village itself based on diversity, participation, genuine autonomy, democracy and community empowerment to manage and build their respective villages.

\section{References}


[1] Z. Nahruddin, "AKUNTABILITAS DAN TRANSPARANSI PENGELOLAAN DANA ALOKASI DESA DI DESA PAO-PAO KECAMATAN TANETE RILAU KABUPATEN BARRU," Otoritas J. Ilmu Pemerintah., 2014.

[2] J. Nusantoro, A. Rosid, and Sudarmaji, "Penerapan Transparansi dan Akuntabilitas Penggunaan Dana Desa Melalui Sistem WEB Laporan Keuangan Berbasis Web," in Senadimas, 2019.

[3] S. Syamsi, "PARTISIPASI MASYARAKAT DALAM MENGONTROL PENGGUNAAN ANGGARAN DANA DESA," J. Ilmu Sos. dan Ilmu Polit. Univ. Tribhuwana Tunggadewi, 2014.

[4] A. M. Purnomo, "PEMBERDAYAAN SOSIAL DALAM PENGEMBANGAN EKOWISATA DI PEKON KILUAN NEGRI, KABUPATEN TANGGAMUS, PROVINSI LAMPUNG,” $J$. Kesejaht. Sos., 2018.

[5] S. Mada, L. Kalangi, and H. Gamaliel, "Pengaruh Kompetensi Aparat Pengelola Dana Desa, Komitmen Organisasi Pemerintah Desa, dan Partisipasi Masyarakat Terhadap Akuntabilitas Pengelolaan Dana Desa Di Kabupaten Gorontalo," J. Ris. Akunt. DAN Audit. "GOODWILL," 2017.

[6] A. S. Dewanta, "Otonomi dan Pembangunan Daerah,” Unisia, 2004.

[7] Buku Pintar Dana Desa, "Buku Pintar Dana Desa,” Buku Pint. Dana Desa, 2017.

Thomas, 2013.PengelolaanAlokasi Dana DesaDalamUpayaMeningkatkan Pembangunan di DesaSebawangKecamatanSesayapKabupatenTanaTidung. eJournalUniversitasMulawarman, 2013, 1(1): 51-64.

Undang-undangNomor 32 Tahun 2004 tentangPemerintahan Daerah. 